EFFECT OF BALADY AND IMPORTED GHICKPEA ON BLOOD GLUCOSE AND LIPID PROFILE OF DIABETES RATS

\author{
By \\ Yasser Mahmoud Ebrahim
}

Assistant prof. of nutrition and food science, home economics department, faculty of specific education, Ain Shams University

Research Gournal Specific Fducation

Faculty of Specific Fducation

Mansoura University

ISSUE NO. 50, APRIL. 2018

مجلة بحوث التربية النوعية - جامعة المنصورة

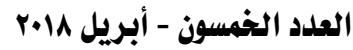




\title{
Effect of balady and imported Chickpea on Blood Glucose and lipid profile of Diabetes Rats
}

\author{
Yasser Mahmoud Ebrahim*
}

\begin{abstract}
Chickpea seeds were reported to have been employed for treating hypertension and diabetes mellitus for over the past 2500 years. The present study aimed to compare the effect of balady and imported chickpea available in Egyptian markets on blood glucose and lipid profile of diabetic rats. Thirty six mature male albino rats were divided into six groups and 30 of them were induced to diabetes and feed with basal diet supported with 10 and $20 \%$ of balady and imported chickpea.The results indicated that, balady chickpea had higher protein, fiber and fat content compared to imported counterpart. Phenolic components were much higher in balady samples than imported counterpart before and after cooking. The feed intake of control group fed on basal diet (control negative) tended to have the highest percentage, followed by diabetic group (control positive) and diabetic group feed on $10 \%$ of balady chickpea. Groups fed on balady chickpea tended to have blood glucose lower than its imported chickpea counterparts. Significant differences were observed between them. The TG, cholesterol, LDL, VLDL levels were significantly $(\mathrm{P}<0.05)$ lower in groups fed on balady chickpea groups compared to diabetic rats fed on imported chickpea groups. It could be concluded that chickpea seeds are a relatively cheap source of dietary fiber and bioactive compounds, which may be useful for lowering the risk of diabetic rats
\end{abstract}

Key words: Chickpea seeds, blood glucose, lipid profile, nutritional diabetes rats

\section{Introduction}

Chickpea (Cicer arietinum) belongs to the Fabaceae family and subfamily Faboidea (Deshpande, 1992). It is an important part of diet in Asia, Central and South America (Nestares., 1996). Chickpea seeds are

* Assistant prof. of nutrition and food science, home economics department, faculty of specific education, Ain Shams University 
grown mainly in the Mediterranean area, the Near East, Central Asia and America. Both Kabuli Chana and Desi Chana variety is used invariably both in Pakistan and India (Zia- et al., 2007).

Cicer arietinum $\mathrm{L}$ is one of the oldest and most widely planted legumes in the world. Its common name (chickpea). it is an important food because it is rich in high-quality protein, carbohydrates and essential mineral elements (White et al., 2009). Chickpea is cholesterol free and is a good source of dietary fibre (DF), vitamins and minerals (and 2007).

C. arientum is known by several names throughout the world such as Bengal gram (Indian), Chickpea (English), Garbanzo (Latin American), Hommes, Hamaz (Arab world), Shimbra (Ethiopian), Nohud, Lablabi (Turkey) (Sagili., 2015).

Studies have shown that chickpea is beneficial for heart burns, skin diseases, blood disorders, biliousness, liver, spleen and bronchitis (Sastry et al, 1990).

Chickpea also possess several medicinal properties. In traditionally system of medicine, chickpea seeds were used as tonic, stimulant, aphrodisiac, anthelminthic, appetizer and for relieving burning sensation in stomach (Zia et al., 2007). In Chinese herbal medicine, chickpea seeds were reported to have been employed for treating hypertension and diabetes mellitus for over the past 2500 years (Li,., 2008).

The epidemiological prevalence of the noncommunicable metabolic disorders such as hypercholesterolemia leading to cardiovascular diseases (CVDs) and of diabetes mellitus has risen tremendously in developing countries like Pakistan due to excessive consumption of junk food (Kouris and beskl, et al., 2016).

Chickpeas have also been widely used in traditional Uighur medicine to treat and prevent hypertension, hyperlipidemia, diabetes, itchy skin, flatulence, low libido, tumor formation and osteoporosis (Liu et al., 1986).

Various substance have been tested for hypoglycemic and hypocholesterolemic effects (Abdel-Sattar et al., 2011), however, there is a 
need to focus on health benefits of foods such as chickpea which are consumed by the local population. Moreover, among the medicinal properties attributed to chick pea, antihyperlipidemic activity has received much attention due to the presence of phytoestrogenic isoflavones biochanin-A and formononetin ( $\mathrm{Li} \mathrm{YH,} \mathrm{et} \mathrm{al.,} \mathrm{2008).}$

The present study compares the effect of balady and imported chickpeaavailable in Egyptian markets on blood glucose and lipid profile of induced diabetic rats.

\section{Material and Methods}

\section{Sample:}

Egyptian and imported Chickpea were purchased from local market in Abasia government, Cairo, Egypt, during summer 2016. Both varides of chickpea were ground into flour.

\section{Chemicals and kits:}

Kits for biochemical analysis were purchased from the gamma trade company for pharmaceutical and chemicals, Dokki, Egypt. Chemicals from EL - Gomhorya company cairo, city ,Egypt .

\section{Chemical evaluation of Egyptian and imported Chickpea}

The nutritional composition of the raw ground samples of Egyptian and imported Chickpea were determined according to (AOAC, 2007).

\section{Determination of Total Phenolic Content}

Total phenolic content was determined with the Folin-Ciocalteu reagent according to a procedure described by Singleton and Rossi 1965. Gallic acid was used as a reference standard, and the results were expressed as milligram gallic acid equivalent (mg GAE)/g dry weight of herbal material.

\section{Antioxidant activity (DPPH radical scavenging assay)}

DPPH radical scavenging activity was done using the reported method (Yamaguchi et al., 1998) . The radical scavenging activity was measured as a decrease in the absorbance of DPPH and calculated using the 
- Effect of balady and imported Chickpea on Blood Glucose and lipid profile of Diabetes Rats

following equation: Effect of scavenging $(\%)=[1-\mathrm{A}$ sample $(517 \mathrm{~nm}) / \mathrm{A}$ control $(517 \mathrm{~nm})] \times 100$

\section{Preparation of dried chickpea.}

The chickpea was coarsely ground to separate the outer crust by sieving through sieve of 200-300 pore size. The ingredients were mixed in a room with defused light and diet pellets were made and oven dried at a very low heat. These pellets were then stored in plastic containers with air tight fitted lids in a cool and dark place until further use.

\section{Animals:}

Thirty six mature male albino rats of Sprague Dawley strain weighing $(175 \pm 10 \mathrm{~g})$ and (12-14 weeks old) were purchased from Laboratory of Animal Colony Helwan Egypt.

\section{Induction of diabetes}

Diabetes was induced in three groups with ALX monohydrate (Simga-Alddrich Company) after $12 \mathrm{~h}$ of fasting. The animals were administered an IV doze of Alloxan monohydrate dissolved $(0.9 \%$ saltine solution) at $70 \mathrm{mg} / \mathrm{kg}$ (Orsolic et al., 2011), intravenously at the coccygeal lateral vein of the rat (Ashok-Kumar et al., 2011). Immediately after ALX monohydrate injection the rats were given glucose diluted in water to prevent hypoglycemia. Blood glucose level was determined at $0 \mathrm{~h}$ and $10 \mathrm{~h}$ after ALX injection ascertain the glucose level, which should be $<200 \mathrm{mg} / \mathrm{dl}$.

\section{Animal diet}

Basal diet was prepared according to (Reeves., 1993).The basal diet were fed to both two control groups.

\section{ExperimentalDesign:}

Rats were maintained under controlled hygienic conditions. Animals were fed on basal diet and water was provided ad libitum. Rats were allowed to acclimatize to the laboratory environment for 7 days before starting of the experiment. The experiment was performed on thirty six adult Sprague Dawley rats weighted $(175 \pm 10 \mathrm{~g})$ randomly distributed into 6 groups, of 6 animals each. 
Group (1) of healthyrats were fed on basal diet and served as a negative control, while, group (2) of rats was induced to diabetes and fed with basal diet and kept as a positive control. Groups (3) and (4) of rats were induced to diabetes and fed on basal diet supported with 10 and 20\% of powder balady chickpea, respectively On the other hand Groups (5) and (6) of rats were induced to diabetes and fed on basal diet supported with 10 and $20 \%$ of powder imported chickpea, respectively.

Food intake was calculated daily and body weight gain was recorded weekly. At the end of the experimental period, the rats were euthanized by prolonged exposure to ether and blood samples were withdrawn for separating the serum by centrifugation at $8000 \mathrm{rpm}$ for $15 \mathrm{~min}$. Serum samples were kept frozen at $-70 \dot{C}$ till biochemical analyses.

\section{Measurement of Biochemical parameters:}

\section{A- Lipid profile}

Serum levels of TC, TG, and HDL-C were determined using enzymatic kits according to the manufacturer's instructions. The LDL-C was estimated by the method of (Friedwald et al., 1972).

\section{B-Determination of serum glucose:-}

Serum glucose concentration was determined according to the methods described by Young, (2001) using Spectrophotometer DU7400 adjusted at $500 \mathrm{~nm}$.

\section{Statistical Analysis}

All values were expressed as mean \pm S.D. The significance of differences between the means of the treated and un-treated groups had been compared by one-way analysis of variance (ANOVA), followed by Student's T test and $\mathrm{P}$ values less than 0.05 were considered significant.

\section{Results and discussion}

Table (1) showed the proximate analysis of balady and imported chickpea. Balady chickpea had higher protein, fiber and fat content compared to imported counterpart. Imported chickpea on the other hand had higher ash content and moisture compared to balady chickpea. From table 
(1) it could be concluded that both of balady and imported chickpea are rich on carbohydrate. This results are agree with several studied that reported chickpea is rich in carbohydrates; however, the chickpea variety can have up to $59 \%$ of carbohydrates (Hamidand Kalsoom, 2017).

The dietary fiber content isin higher in balady chickpea 6.5 to $6.6 \%$ as compared to 4.3 to $4.7 \%$ of imported chickpea variety. Fiber content in balady type is higher than reported by other study, whereas, fiber content for imported ones is agree with the same study (Maheri-Sis et al., 2008).

Table (1) chemical composition of balady and imported Chickpea before and after cooking

\begin{tabular}{|c|c|c|c|c|c|}
\hline \multirow{3}{*}{\multicolumn{2}{|c|}{ Elements }} & \multicolumn{4}{|c|}{ Samples } \\
\hline & & \multicolumn{2}{|c|}{ Before cooking } & \multicolumn{2}{|c|}{ After cooking } \\
\hline & & balady & imported & Balady & Imported \\
\hline & total proteins $\%$ & 26.2 & 22.4 & 30.6 & 25.9 \\
\hline & Fat $\%$ & 6.3 & 6.5 & 6.1 & 6.1 \\
\hline & Fibers $\%$ & 10.6 & 6.3 & 9.5 & 5,7 \\
\hline & Ash $\%$ & 2.1 & 2.7 & 1.15 & 1.2 \\
\hline & Moisture $\%$ & 5.3 & 5.8 & 10.2 & 11.6 \\
\hline \multirow{2}{*}{$\begin{array}{c}\text { phenolics } \\
\text { analysis } \\
(\mathrm{mg} / \mathrm{g})\end{array}$} & total phenolics ((mg GAE/g) & 112 & 61 & 51 & 32 \\
\hline & Antioxidant activity (DPPH) & 10.3 & 8.8 & 21.8 & 13.7 \\
\hline
\end{tabular}

The protein ranges from $22-30 \%$ in both the varieties. This result is agree with (Zia-Ul-Haq et al., 2007) study whom reported that the level of protein can be vary depending on their subtype.

Phenolic components were much higher in balady samples than imported counterpart before and after cooking. Isoflavones are diphenolic secondary metabolites that may lower the incidence of heart disease due to the inhibition of LDL-C oxidation, the inhibition of proliferation of aortic smooth muscle cells and the maintenance of the physical properties of arterial walls (Panter et al. 2001). 
From the data presented in table (2), it could be observed that, the feed intake of control group fed on basal diet (control negative) tended to have the highest percentage, followed by diabetic group (control positive) and diabetic group feed on $10 \%$ of balady chickpea. Other treated groups tended to have the similar feed intake, even no significant differences were observed between them. Feed intake for all diabetic rats treated with different doses or types of chickpea were lower than control positive. It may be due to chickpea contain high amount of fiber which reduce feed intake (Luis et al., 2017).

Control negative group have the highest body weight gain (BWG $\%$ ), even significant difference was observed between this group and other groups. Diabetic rats feed on imported chickpea tended to have BWG\% significant higher than diabetic rats feed on balady chickpea. This result was within with Albete et al., 2010 opinion whom reported that,chickpea high in fiber, low in energy density and glycemic load, and moderate in protein are thought to be particularly important for weight control (Albete et al., 2010).

Table (2): Effect of different ratio of balady and imported chickpea on feed intake, body weight gain $\%$ and Feed efficiency ratio of diabetic rat groups.

\begin{tabular}{||c|c|c|c||}
\hline \hline Proups & $\begin{array}{c}\text { Feed intake } \\
\text { (g/day) }\end{array}$ & (BWG\%) & Feed efficiency ratio \\
\hline \hline Control negative group $(-)$ & $17.44+3.13 \mathrm{a}$ & $26.92+7.15 \mathrm{a}$ & $0.062+0.016 \mathrm{a}$ \\
\hline Control positive group $(+)$ & $16.27+2.12 \mathrm{a}$ & $10.83+3.18 \mathrm{c}$ & $0.022+0.003 \mathrm{c}$ \\
\hline Balady chickpea 5\% & $15.39+2.91 \mathrm{~b}$ & $9.92+5.17 \mathrm{c}$ & $0.023+0.009 \mathrm{~d}$ \\
\hline Balady chickpea 10\% & $16.88+3.26 \mathrm{a}$ & $10.71+6.87 \mathrm{c}$ & $0.026+0.010 \mathrm{c}$ \\
\hline Imported chickpea 5\% & $15.98+3.12 \mathrm{~b}$ & $17.86+3.35 \mathrm{~b}$ & $\mathbf{0 . 0 3 1 + 0 . 0 0 6 b}$ \\
\hline Imported chickpea 10\% & $14.10+2.85 \mathrm{c}$ & $19.65+1.07 \mathrm{~b}$ & $0.035+0.008 \mathrm{~b}$ \\
\hline
\end{tabular}

$\mathrm{SD}=$ Standard division. ${ }^{* * *} P<0.005$. Values are mean \pm SD. One-way ANOVA followed by Tukey's post-hoc test. Mean with different superscripts are significantly different $(P<0.05)$ 
- Effect of balady and imported Chickpea on Blood Glucose and lipid profile of Diabetes Rats

Table (3): Effect of different ratio of balady and imported chickpea on blood glucose of diabetic rats.

\begin{tabular}{||c|c|c|c||}
\hline Groups & $\begin{array}{c}\text { Initial blood } \\
\text { glucose }\end{array}$ & $\begin{array}{c}\text { Blood glucose } \\
\text { after 2 weeks }\end{array}$ & $\begin{array}{c}\text { Final blood } \\
\text { glucose }\end{array}$ \\
\hline Control negative (-) & $101.44 \pm 20.11 \mathrm{a}$ & $99.35 \pm 10.12 \mathrm{a}$ & $98.39 \pm 16.91 \mathrm{a}$ \\
\hline Control positive (+) & $100.22 \pm 18.92 \mathrm{a}$ & $260.15 \pm 30.21 \mathrm{e}$ & $269.87 \pm 25.12 \mathrm{~d}$ \\
\hline Balady chickpea 5\% & $99.40 \pm 17.75 \mathrm{a}$ & $226.88 \pm 22.18 \mathrm{C}$ & $219.32 \pm 14.10 \mathrm{c}$ \\
\hline Balady chickpea 10\% & $100.83 \pm 21.08 \mathrm{a}$ & $216.32 \pm 24.01 \mathrm{~b}$ & $201.10 \pm 12.65 \mathrm{~b}$ \\
\hline Imported chickpea 5\% & $101.09 \pm 12.85 \mathrm{a}$ & $238.12 \pm 19.32 \mathrm{~d}$ & $222.78 \pm 15.51 \mathrm{c}$ \\
\hline Imported chickpea 10\% & $100.11 \pm 18.10 \mathrm{a}$ & $221.61 \pm 15.54 \mathrm{bc}$ & $210.03 \pm 9.89 \mathrm{~b} \mathrm{C}$ \\
\hline
\end{tabular}

Mean with different superscripts are significantly different $(P<0.05)$

Values are mean \pm SD.

Table 3 shows Blood glucose level of all the four treatment groups. Control group fed on basal diet showed no significant change in the blood glucose level over the entire period of the experiment. The diabetic group fed on basal diet (control positive) showed a significant increase in the blood glucose level (from $99.35 \mathrm{mg} / \mathrm{dl}$ to $260.15 \mathrm{mg} / \mathrm{dl}$ ) during the first two weeks. This increase in the blood glucose level remained on the higher side almost throughout the observation period of 8 weeks.

The blood glucose level of diabetic group fed on both balady and imported chickpea after the induction of diabetes showed a great increase in the blood glucose level (from approximately $100 \mathrm{mg} / \mathrm{dl}$ to over $200 \mathrm{mg} / \mathrm{dl}$ ) during 8 weeks compared to zero week. After this increase recorded during the 2 nd and there was a significant decrease in blood glucose level which was maintained till the end of experiment.

It should be noted that, there was no significant difference $(\mathrm{p}<0.05)$ in the random blood glucose level (RBGL) of normal and all other experimental groups at week 0 . The RBGL of group fed on both types of chickpea remained significantly $(\mathrm{p}<0.05)$ lower than that of the diabetic group (control positive) throughout the experimental period. From the above mentioned data, it could be concluded that, groups fed on balady chickpea 
tended to have blood glucose lower than its imported chickpea counterparts. Even significant differences were observed between them.

The results of the present study suggest that both typesof the chickpeas have a blood glucose lowering effect inthe diabetic rats. It may be due to Chickpeas have an glycemic index of 10, which is significantly lower than other beans, including black beans, navy beans, soybeans and lentils (Hamid and Kalsoom, 2017).This result was within with Tiwari et al. (2013) studyshowed thatchickpea is beneficial indiabetic rats.

A similar study conducted by Nestel et al. (2004) on the effect of a single meal of chickpea on plasma glucose, insulin and triglyceride levels showed that after the chickpea meal plasma insulin and HOMA were significantly lower $(\mathrm{P}<0.05)$ as compared to the regular meal.

\section{Effect on serum lipid profile}

The mean serum total cholesterol and HDL cholesterol was significantly $(\mathrm{P}<0.05)$ increased in the control positive group compared to control negative group. Whereas, both types of chickpea showed significantly $(\mathrm{P}<0.05)$ lower values as compared to control positive group.

Table (4): Effect of different ratio of balady and imported chickpea on serum lipid profile of diabetic rats $(\mathbf{m g} / \mathbf{d l})$.

\begin{tabular}{|c|c|c|c|c|c|}
\hline Groups & T.G & Cholesterol & VLDL & LDL & HDL \\
\hline Control negative $(-)$ & $86.40 \pm 6.11^{\mathrm{d}}$ & $83.40 \pm 0.89^{\mathrm{c}}$ & $19.00 \pm 1.22^{b}$ & $18.00^{\mathrm{bc}} \pm 4.06$ & $50.60 \pm 3.21^{\mathrm{a}}$ \\
\hline Control positive $(+)$ & $112.80 \pm 9.09^{\mathrm{a}}$ & $95.40 \pm 4.10^{\mathrm{a}}$ & $24.20 \pm 1.92^{\mathrm{a}}$ & $33.20 \pm 1.30^{\mathrm{a}}$ & $32.60^{\mathrm{e}} \pm 2.30$ \\
\hline Balady chickpea 5\% & $92.20 \pm 1.10^{\mathrm{c}}$ & $87.22 \pm 8.2^{\mathrm{b}}$ & $21.00 \pm 2.10^{\mathrm{a}}$ & $21.40 \pm 2.61^{\mathrm{b}}$ & $44.40 \pm 1.52^{b}$ \\
\hline Balady chickpea $10 \%$ & $87.40 \pm 4.28^{\mathrm{d}}$ & $83.20 \pm 2.49^{\mathrm{c}}$ & $19.00 \pm 0.71^{\mathrm{b}}$ & $19.20 \pm 7.43^{\mathrm{b}}$ & $47.40 \pm 4.51^{\mathrm{a}}$ \\
\hline Imported chickpea 5\% & $105.20 \pm 1.30^{\mathrm{b}}$ & $89.80 \pm 1.30^{b}$ & $22.60 \pm 0.55^{\mathrm{a}}$ & $24.20 \pm 9.03^{b}$ & $42.00 \pm 2.92^{b}$ \\
\hline Imported chickpea $10 \%$ & $101.41 \pm 9.50^{\mathrm{b}}$ & $84.80 \pm 0.84^{\mathrm{c}}$ & $22.00 \pm 2.35^{\mathrm{a}}$ & $21.80 \pm 4.66^{\mathrm{b}}$ & $39.60 \pm 2.97^{\mathrm{c}}$ \\
\hline
\end{tabular}

$\mathrm{SD}=$ Standard division. ${ }^{* * *} P<0.001$. Values are mean \pm SD. One-way ANOVA followed by Tukey's post-hoc test. Mean with different superscripts are significantly different $(P<0.05)$ 
Mean HDL cholesterol was significantly $(\mathrm{P}<0.05)$ higher in groups treated with chickpea than control positive group. The mean TG, cholesterol, LDL, VLDL and LDL content was significantly $(\mathrm{P}<0.05)$ higher in control positive group compared to all other groups; whereas, diabetic treated groupswith two types of chickpea had significantly $(\mathrm{P}<$ 0.05) lower TG, cholesterol, LDL, VLDL and LDL levels (Table 4). It may be due to both types of fiber had high amount of fiber. In general, increased consumption of soluble fibre from foods results in reduced serum total cholesterol and LDL-cholesterol (LDL-C) and has an inverse correlation with CHD mortality (James et al., 2003).

The TG, cholesterol, LDL, VLDL levels were significantly $(P<$ $0.05)$ lower in groups fed on balady chickpea groups compared to diabetic rats fed on imported chickpea groups. On contrast the level of HDL were significantly $(P<0.05)$ higher in groups fed on balady chickpea groups compared to diabetic rats fed on imported chickpea groups at the same amount.

Chickpea has a high total dietary fibre content and a higher amount of fat. But other study confirmed that, two PUFA, LA and OA, constitute almost about $50-60 \%$ of chickpea fat. Intake of PUFA such as LA (the dominant fatty acid in chickpea; Table 4) has been shown to have a beneficial effect on serum lipids, insulin sensitivity and haemostatic factors, thereby it could be helpful in lowering the risk of CHD (Harris 2000)

\section{CONCLUSIONS}

The nutritional evaluation of balady and imported chickpea showed that balady one had higher protein, fat content, total phenols and antioxidant activity. Both types of chickpea high fiber diet decreased the blood glucose level of the STZ-induced diabetic rats during eight weeks of experiment comparedto the diabetic control positive group. Balady chickpea have higher fiber diet than imported counterpart and can reduced the blood glucose level, total cholesterol and triglyceride of the diabetic rats significantly more than the imported chickpea.It could be concluded that Chickpea seeds are a relatively cheap source of DF and bioactive 
compounds; coupled with its low glycaemic index (GI), chickpea may be useful for lowering the risk of CVD

\section{References}

- Abdel-Sattar, E., Harraz, F.M., Ghareib, S.A.,Elberry, A.A., Gabr, S. and Suliaman, M.I., (2011): Antihyperglycaemic and hypolipidaemic effects of the methanolic extract of Carallumatuberculata in streptozotocin-induced diabetic rats. Nat. Prod. Res., 25: 1171-1179.

- Albete I., Astrup A., Martinez J.A., Martinez J.A., Thorsdottir I.and, Zulet M.A.( 2010): Obesity and the metabolic syndrome: Role of different dietary macronutrient distribution patterns and specific nutritional components on weight loss and maintenance. Nutr. Rev.;68:214-231.

- AOAC (2007).: Official Methods of Analysis of AOAC International, 18th ed. Association of Official Analytical Chemists, Washington,DC. USA.

- Ashok Kumar, B.S. , Lakshman, K., Jayaveea, K.N., Sheshadri Shekar, D. and Saleemulla Khan, D (2012): Antidiabetic, antihyperlipidemic and antioxidant activities of methanolic extract of Amaranthus viridis Linn in alloxan induced diabetic rats, Experimental and Toxicologic Pathology, Volume 64 (1), 75-79.

- Deshpande, S.S., (1992): Food legumes inhuman nutrition: a personal perspective.Rev. Fd. Sci Nutr., 32: 333-363.

- Friedwald W,Levy R, Fredricken D (1972). Estimation of HDL-C in the plasma without the use of preparative ultracentrifuge. Clinical Chemistry.

- Hamid A and Kalsoom S (2017). Comparative Analysis of Nutritional Composition and Effect of Dietary Fiber Extracts of Chickpea and Bengal Gram on Blood Glucose and Cholesterol Levels of Male Induced Diabetic and Hypercholesterolemic Rats, Pakistan J. Zool., vol. 49(2), pp 487-492.

- Harris, M. (2000): Definition and classification of diabetes mellitus and the new criteria for diagnosis. Diabetes mellitus, A fundamental and clinical text 2nd. Lippincott Williams and Wilkins. A Wolters Kluwer Company. 326-333.

- James SL, Muir JG and Curtis SL (2003): Dietary fibre roughage guide. Intern Med J 33, 291-296. 
- Effect of balady and imported Chickpea on Blood Glucose and lipid profile of Diabetes Rats

- Luis A, George G, Peter D, David B, Maureen A. Susan B and Arpad P (2017): Nutritional Utilization by Rats of Chickpea (Cicer arietinum) Meal and Its Isolated Globulin Proteins Is Poorer than That of Defatted Soybean or Lactalbumin, J. Sci. Food Agric. 67: 235 - 238.

- Liu YM, Yikemu S. Wei Wu and Yao Zhi(1986): 1st ed. Urumqi (Xinjiang) Xin Jiang People's Publishing House; p 469-71.

- Li YH, Jiang B, Zhang T, Mu W, and Liu J(2008):. Antioxidant and free radical-scavenging activities of chickpea rotein hydrolysate $(\mathrm{CPH})$. Food Chem;106:444-50.

- Maheri-Sis, N., Chamani, M., Ali-Asghar, S., Mirza- Aghazadeh, A. and Aghajanzadeh-Golshani, A.,(2008): Nutritional evaluation of Kabuli and desi type chickpeas (Cicer arietinum L.) for ruminants using in vitro gas production technique. Afri. J.Biotech., 7: 2946-2951.

- Nestel, P., Marja, C. and Chronopoulos, A., (2004): Effects of long-term consumption and singlemeals of chickpeas on plasma glucose, insulin, and triacylglycerol concentrations. Am. J. clin. Nutr., 79: 390-395.

- Nestares, T., López-Frías, M., Barrionuevo, M. and Urbano, G., (1996): Nutritional assessment of raw and processed chickpea (Cicer arietinum L.) protein in growing rats. J. Agric. Fd. Chem., 44: 2760-2765.

- Orsolic, N., A.H. Knezevic, L. Sver, S. Terzic, B.K. Heckenberger and I. Basic.( 2003): Influence of honey bee products on transplantable murine tumours. Vet. Comp. Oncology, 1: 216-226.

- Kouris A and Belski R (2016): Health benefits of legumes and pulses with a focus on Australian sweet lupins. Asia Pac J Clin Nutr;25 (1):1-17.

- Panter, K.E., Mayland, H.F, Gardner, D.R and Shewmaker, G. (2001): Beef cattle losses after grazing Lupinus argenteus ( Salivery Lupine). Vet. Human. Toxicol., 43(5): 279-282.

- Reeves, P. G.; Nielsen, F. H. and Fahmy, G. C. (1993): Report of the American Institute of Nutrition adhoc wriling committee on the reformulation of the AIN. 76 A Rodent diet. J. Nutrition; 123: 1939 - 1951. 
- Sagili Harini, Kaliki Adilaxmamma, Emani Madan Mohan, Ch. Srilatha, Mekapogu Alpha Raj (2015): Antihyperlipidemic activity of chickpea sprouts supplementation in ovariectomyinduced dyslipidemia in rats, Journal of Ayurveda \& Integrative Medicine, Vol 6/ 2, 104:110.

- Sastry, C.S.T. and Kavathekar, K.Y.,( 1990): Plants for reclamation of wastelands. Council of Scientificand Industrial Research, New Delhi, India, p. 684.

- Singleton, V.L.; Rossi, J.A. (1965): Colorimetry of total phenolics with phosphomolybdicphosphotungstic acid reagents. Am. J. Enol. Vitic., 16, 144158.

- Tiwari, A., Sahana, C., Zehra, A., Madhusudana, K., Anand, D. and Agawane, S., (2013): Mitigation of starch-induced postprandial glycemic spikes in rats by antioxidants-rich extract of Cicer arietinum Linn. seeds and sprouts. J. Pharm. biol, Sci., 5: 270.

- Tronc E. (1999): Lupin flour: a new ingredient for human food. Grains Legumes, 25: 3, 24.

- Wood JA and Grusak MA (2007): Nutritional value of chickpea. In Chickpea Breeding and Management, pp. 101-142 [SS Yadav, R Redden, W Chen and B Sharma, editors]. Wallingford: CAB International.

- White PJ, Broadley MR (2009):. Biofortification of crops with seven mineral elements often lacking in human diets — iron, zinc, copper, calcium, magnesium, selenium and iodine. New Phytologist 2009; 182: 49-84.

- Yamaguchi T, Takamura H, Matoba $T$ and Terao (1998) J, Biosci Biotechnol Biochem., 62, 1201-1204.

- Young D S and Friedman RB. 2001. Effects of Disease on Clinical Labratory Tests, 4th ed, Washington, AACC Press.

- Zia-Ul-Haq, M., Iqbal, S., Ahmad, S., Imran, M., Niaz, A. and Bhanger, M.I., (2007): Nutritional and compositional study of desi chickpea (Cicer arietinum L.) cultivars grown in Punjab, Pakistan. Fd. Chem., 105: 1357-1363. 


\section{تهليل همارن للامشتوي التغذذوي وتأثير المصص البلادي والمستوردة على همتوى البلوكمز في الدم وصورة دهون الدم لدى الفئران الاصابة بالسكري \\ إعداد \\ ياسر محمود ابراهيمعلويـ}

unil|

تستخدم بلذور الحمص لعلاج ارتفاع ضغط الدم وداء السكري لأكثر من ل. ب0 سنة ماضية.

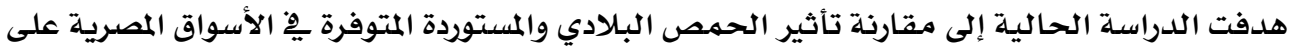

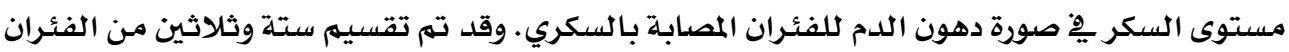

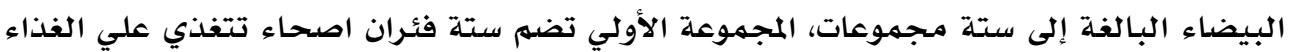

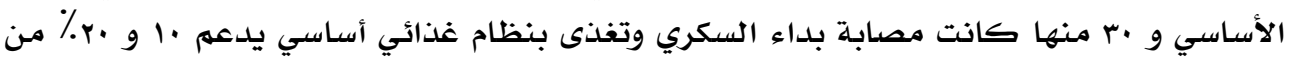

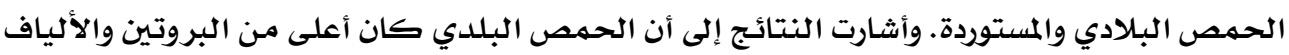

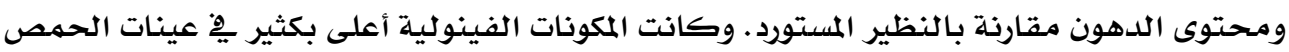

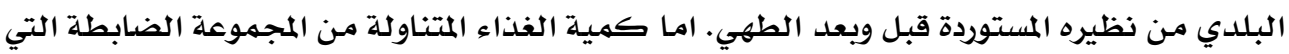

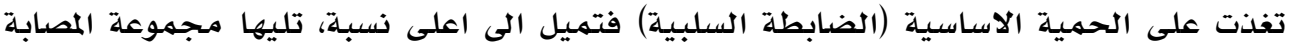

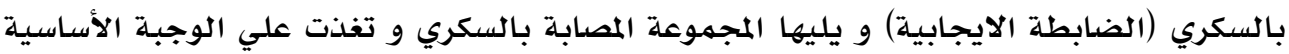

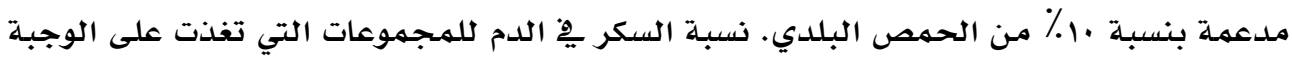

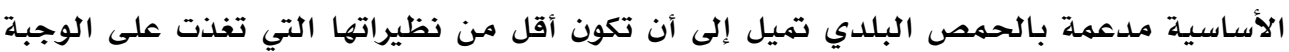

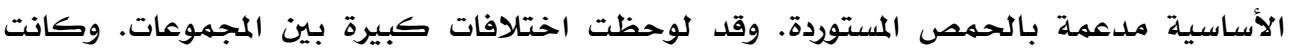

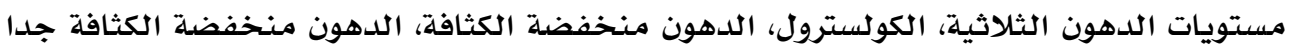

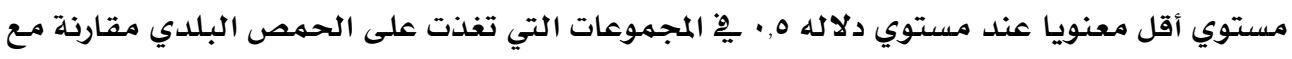

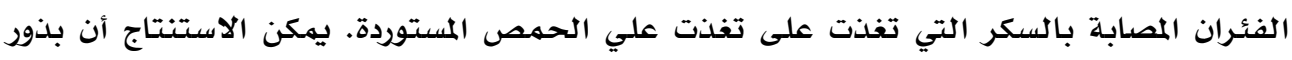

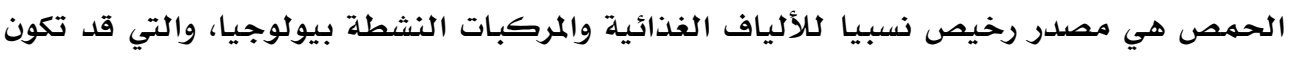
مفيدة لخفض خطر الإصابة بالسكر من الفئران.

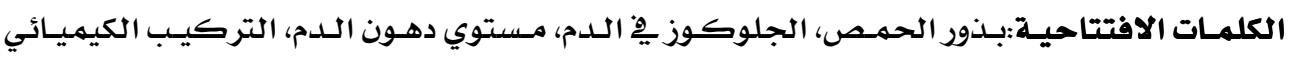
والفئران 